\title{
TÂNĂRUL CREȘTIN SAU APOLOGIA FRUMOSULUI MORAL VERSUS SURÂSUL TRIST AL NEDUMERIRII ÎN SOCIETATEA SECULARIZANT-POSTMODERNĂ
}

Răzvan Brudiu*

Abstract: The Young Christian or the Moral Beauty Apology versus the Sad Smile of Bewilderness in the Post-Modern Secularized Society. The young people of our times live in a time of changes, very challenging for the Christian faith and mission. They are inclined to choose between different fragments of truth, several thinking systems and concepts according to their way of seeing the reality or to their opinions upon the spiritual growth. The religious syncretism is more and more present nowadays and begins to be part in the existence of the postmodern young people. Postmodernism creates a series of difficulties for them: hesitating thoughts, difficulties in accepting various pieces of truth related to faith and morality, not corresponding to their own thoughts. Thus, all these seem to limit and obstruct the manifestation of the human liberty. The Church is a real defender and keeper of the human values, meaning the sacred values of life, liberty, family and human solidarity. The young people need the Church and the Church needs the young people.

The postmodern society develops an existential system that tries to cultivate some anti-Christian and antireligious mentalities. If the old atheism used to present itself in a decent manner and with respect for good social relations, we observe today that we deal with an unprecedented nihilism and unnatural manifestations and attitudes that determine extreme terrorist violence. The postmodern mentality inevitably leads to secularism, which is more dangerous than the atheism, because it benefits of a false mask of declaring a religious appurtenance.

The present study does not intend a complex analyse of the problems linked to the life of the young people. It mainly intends to present some pastoral methods for Christ and Church to meet and guise the young people, more and more confronted with dilemmas, problems and the challenges of the contemporary world.

Keywords: young people, mission, postmodernism, contemporary challenges, consumerism.

* PhD, Faculty of Orthodox Theology, "1 Decembrie 1918” University, Alba Iulia, Romania. 


\section{Introducere}

Societatea în care trăiesc tinerii de azi este dispersată și apare tot mai mult ca un arhipelag fragmentat, în care nu mai sunt prezente concepții despre lume, viziuni despre viață și sisteme de valori. Concepțiile de viață actuale ale tinerilor nu mai propun un Adevăr ci impun mai multe adevăruri, astfel încât este nevoie, imperios, de întoarcerea la un sistem care să reușească să integreze diversitatea și să propună drept idealuri valori capabile să creeze o imagine de ansamblu unitară. Unitatea și claritatea ar trebui să reprezinte o exigență naturală a oricărui tânăr creștin.

Tinerii societăţii actuale sunt niște oameni bine instruiți, au acces la informație, cunosc foarte multe lucruri, sunt în pas (sau încearcă să fie în pas) cu toate tendințele vremii, preconizează tot felul de sisteme și de valori, încearcă să imite personalități din lumea sportului, filmului, muzicii, însă, cu toate acestea, le lipsește un singur lucru, și anume orientarea către Hristos. Orientarea către Hristos o descoperim prin Biserică, însă în prezent acest adevăr este combătut de către foarte mulți tineri, care au preluat acest comportament din mesajele pe care mass-media le propagă atât de intens. Observăm faptul că astăzi, mai mult ca oricând, tinerii nu sunt atât împotriva lui Hristos, cât împotriva unui clericalism instituționalizat al Bisericii. Având contact cu tinerii în fiecare zi, atât la clasă în timpul orelor, cât și în activitățile extrașcolare, mi-am dat seama că aceștia preferă un Dumnezeu pur și simplu, și nu un Dumnezeu sofisticat și complicat. Pentru foarte mulți, viața în Hristos mai poate însemna ceva interesant, dar viața în Biserică, așa cum este ea, cu cântările lungi și neclar reproduse, cu preoți îmbrăcați în veșminte extravagante, cu slujbe lungi, nu îi mai seduce și nu o mai găsesc atractivă.

Studiul de față nu își dorește neapărat o analiză complexă a problemelor legate de viața tinerilor, ci intenționează în principal să prezinte câteva dintre mijloacele pastorale prin care Hristos și Biserica pot ieși în întâmpinarea și călăuzirea tinerilor care se 
confruntă din ce în ce mai des cu dilemele, problemele și provocările lumii contemporane.

\section{Tinerețea azi, vârsta - paradox și actualitatea mesajului eclesial}

Cultura de consum și felul în care ea respinge angajamentul tinerilor prezintă o mare provocare în formarea nucleelor acestora în societatea de azi. Ca orice instituție eclezială, mișcările tinerilor au în față pericolul însușirii unei mentalităţi consumiste. Printr-o lentilă consumistă, activitățile și experiențele tinerilor devin mai degrabă o profesie sau un job, și nu o vocație. Parohiile par, în acest fel, să livreze un set de bunuri spirituale tinerilor, care sunt tratați drept consumatori, mai mult decât participanți într-un proces activ. Aceste tendințe sunt parțial vizibile în modelele de leadership, care sunt adoptate de unele asociații destinate tinerilor. $\mathrm{O}$ asemenea transformare a parohiei în livrare de bunuri poartă cu sine multe pericole, incluzând pierderea conducerii adolescenților, competiția între diferite mișcări ale acestora și crearea unor enclave de stil de viață, în care oamenii aleg să participe la grupuri pentru a-și îndeplini dorințele fără concurență ${ }^{1}$.

Un cadru al misiunii tinerilor rămâne relevant în contextul actual, în care atât de mulţi dintre aceștia se simt marginalizaţi şi fără putere în lumea adulților. În contrast cu modelele clericaliste şi consumiste, modelul apostolic situează tinerii ca participanţi activi în lume şi în Biserică. Tinerii nu sunt unelte sau elemente care să fie folosite de oficialii adulţi sau clerici. Nici nu sunt consumatori de servicii spirituale. În virtutea iniţierii lor în Biserică prin cele trei Taine: Botez, Mirungere, Euharistie, tinerii sunt membri deplini

Kevin Ahern, Youth Movements in a Global Church, in "Concilium", International Journal of Theology, t. 2, Edited by Solange Lefebvre, Maria Clara Bingemer, SCM Press, London, 2015, p. 36-37. 
printre oamenii lui Dumnezeu. Ei trebuie să ajungă să simtă că sunt Biserica, experimentând-o ca pe un loc al comuniunii şi participării ${ }^{2}$.

Trebuie menționat încă de la început faptul că există două aspecte fundamentale referitoare la pastoraţia tinerilor:

1. Toți membrii comunității eclesiale, cler și popor, trebuie să participe la viața pastoral-misionară a Bisericii. Există o anumită parte a societății actuale, care afirmă că activitatea pastorală în cadrul Bisericii trebuie lăsată doar în seama ierarhiei bisericești. Această idee este una greșită, deoarece Biserica nu poate exista numai cu ierarhie sau numai cu mireni. Fără îndoială, ierarhia are un rol fundamental în dinamica pastorală și misionară a Bisericii Ortodoxe, însă trebuie să existe o sinergie între cler și poporul lui Dumnezeu ${ }^{3}$.

2. Tinerii trebuie să fie implicați activ în pastorația generației lor, pentru că vârsta apropiată ușurează întotdeauna comunicarea, deschiderea personală, motivează, creează prietenii, identifică mai ușor problemele și utilizează aceleași categorii de preocupări. Aceștia pot fi stimulați să se ocupe de activitățile stabilite de către preotul paroh, în vederea pastorației, fără de care o comunitate eclesială nu este și nu poate fi cu adevărat împlinită ${ }^{4}$.

Se naște întrebarea: Cum îi aducem pe acești tineri mai aproape de Hristos? Întâi de toate, se impune de la sine eliminarea oricăror prejudecăți pe care le au acești tineri despre Biserică, prin încercarea de a le răspunde în timp și de a avea răbdare că rezolvarea va fi posibilă.

„Tânărul trebuie să înțeleagă că Biserica nu este o sperietoare, un spațiu al celor damnați și al celor ce trebuie să se lamenteze la infinit pentru păcatele lor. Nu asta este Biserica. Rolul ei este acela de a tămădui, de a împodobi sufletul omului și nu de a-l pedepsi. Nu blamarea și cearta

\footnotetext{
${ }^{2}$ Ibidem, p. 38-39.

${ }^{3}$ Gheorghe Holbea, Pastorația tinerilor în contextul actual al globalizării, în vol. „Relaţia dintre parohie şi şcoală în viaţa şi misiunea Bisericii din contextul actual", coordonatori: Adrian Lemeni, David Pestroiu, București, Edit. Basilica a Patriarhiei Române, 2015, p. 262.

${ }^{4}$ Ibidem, p. 263.
} 
trebuie să fie prezente în relația preotului cu tânărul, ci bucuria că acela vine la Hristos, chiar dacă are cercel în ureche, blugi rupți şi păr lung. Hristos i-a primit pe toți, fără să facă vreo discriminare pe considerente morale, vestimentare sau mentale. În activitatea Sa misionară, Iisus Hristos a trăit și i-a cercetat pe păcătoși, pe desfrânați, pe vameși și lumea cea mai decăzută din vremea respectivă. Toți acești oameni blamaţi de societatea vremii respective se îndreptau spre Mântuitorul Hristos cu bucurie și curaj, pe când ceilalți, fariseii și cărturarii poporului, n-aveau nevoie de Hristos, cu toate că și pentru aceștia a venit" ${ }^{\prime 5}$.

Tinerii societății actuale au nevoie de îndrăzneală, fără de care nu pot izbândi în viaţă. Îndrăzneala se completează cu speranţa, deoarece ele, conlucrând, pot muta lucruri din loc, pot crea noi direcţii, pot deschide uşi închise şi pot vedea lumea (şi Biserica) întro lumină nouă. Îndrăzneala poate fi, de asemenea, găsită în activitatea și lucrarea lui Iisus Hristos (El Însuşi fiind tânăr), Care în viaţa $\mathrm{Sa}$ a luptat împotriva celor puternici, a liderilor, a timpurilor Sale şi a oferit tuturor, mai ales celor săraci, o nouă şansă pentru viaţă şi pentru libertate. Astăzi, avem nevoie de o îndrăzneală gândită şi măsurată, care trebuie exprimată la persoana întâi, adică să înceapă de la fiecare dintre noi. Desigur, aceste acte de îndrăzneală ne încântă pe mulţi, dar neliniştesc un mare număr de oameni care trăiesc confortabil, închişi şi care nu simt noul aer al Duhului care ne conduce. Duhul ne arată întotdeauna ceea ce este nou şi avem nevoie de îndrăzneală să Îl urmăm pe Hristos. Ideea este să păstrăm ceea ce este esenţial, să privim atent la cine este speranța noastră 6 .

Tehnologizarea și raţionalizarea lumii înconjurătoare atacă mintea avidă după cunoaștere a tânărului modern și o desprind de tot ceea ce înseamnă transcendent, ancorând-o în uman şi material.

5 Ilie Trif, Nu te încuia în deznădejde, în vol. „Paradoxul creștin și cartea tinereții”, Alba Iulia, Edit. Reîntregirea, 2008, p. 248-249.

${ }^{6}$ Cesar Kuzma, Church, Hope and Young People, in "Concilium", International Journal of Theology, t. 2, Edited by Solange Lefebvre, Maria Clara Bingemer, London, SCM Press, 2015, p. 65. 
Biserica are menirea de a lumina acest segment cu o profunzime și abilitate de excepție:

„Teologia vine în întâmpinarea raţiunii, o luminează, o face profundă. În schimb, ştiinţa actuală tinde să aprofundeze limitele raţiunii, ceea ce devine periculos, caută să o împingă spre anumite zone obscure. O pură filozofie despre lume devine scientistă. Unele aplicaţii ale scientismului şi ale mecanicismului radical nu mai sunt posibile. Ceea ce ştim noi este că mişcarea ţine de firea celor create. Ea nu este rea prin sine, cum susţinea origenismul. Ea poate duce firea şi la bine şi la rău. Dar e rânduită să ducă la desăvârşire, adică la Dumnezeu, Binele Absolut. Şi numai făcând aceasta, mişcarea duce la împlinire firea umană. Harul cu care lucrăm mântuirea noastră care ne vine din Hristos este o dovadă a unei miş̧ări a lui Dumnezeu în legătură cu noi, chiar dacă aceasta nu-L coboară din fiinţa Lui. Mişcarea nu este cauza răului"”

Există din partea actualei generații ideea simplificării cultului și a vieții Bisericii în integralitatea ei, însă această tendință nu este una sănătoasă și realistă. Reformele în Biserică pot avea sau nu succesul scontat. Reforma nu înseamnă simplificarea sau anularea unor elemente prezente în cultul și practica Bisericii (aşa cum, din păcate, vedem la anumite confesiuni creștine), ci înseamnă revenirea la forma inițială, revenirea la obârșie, adică la viața Bisericii din primele secole creștine. Simplificarea și dorirea unei Biserici pe gustul generației contemporane ar duce la instaurarea unui nou neoprotestantism și nicidecum spre o ortodoxie curată și înțeleasă în adevăratul sens al cuvântului. Astăzi, nu numai că există o ruptură între tineri și Biserică, ci este mai mult o luptă a tinerilor cu Biserica. Dacă stăm să gândim în profunzime, acesta ar fi un nonsens, deoarece nu pot fi luptători împotriva Bisericii, pentru că ei fac parte din Biserică, ei sunt, de fapt, Biserica.

Prin nebunia frenetică de a fi originali, de a ieși în evidență, de a fi mai altfel decât ceilalți, tinerii contemporani descoperă faptul că sunt singuri, descoperă o serie de drame din viețile lor, pe care nu

${ }^{7}$ Mihai Himcinschi, Confruntări misionare: știința și teologia, în „Altarul Reîntregirii”, serie nouă, anul XI, nr. 2, mai-august, 2006, p. 34. 
le pot ascunde nici cu Coca-Cola, nici cu muzica dată la maximum în căști, nici cu râsul zgomotos, nici cu tenișii Converse și nici cu pantalonii rupți. Toate acestea denotă o mare suferință a tinerilor de azi. Cele menționate nici n-ar fi atât de grave, grav este faptul că toate aceste exteriorizări, toate aceste manifestări, tot efortul pe care îl depun pentru a fi într-un anume fel îi împiedică să își descopere adevărata lor identitate ${ }^{8}$. Felul acesta al tinerilor este provocat de anumite cauze: economice, sociale, culturale, politice, care se axează pe o societate repliată pe prezent și pe imanent. Este o societate care se ghidează pe principiul acum și aici. Totul se bazează pe sloganul: Trăiește clipa. Este o societate care cunoaște o criză puternică a temporalității, adică neputința de a trăi prezentul ca moment al interacțiunii dintre trecut și viitor. Lipsa responsabilității față de trecut și faţă de viitor va atrage după sine o des-responsabilizare, în care societatea nu doar că va refuza să-și recunoască vina pentru greșelile trecutului, ci nu va mai voi nici măcar să și le reamintească, preferând să trăiască într-un prezent anesteziant. O societate care nu învață din erorile trecutului va fi condamnată să le repete şi în prezent, dar şi în viitor. Un astfel de climat există deja, iar numeroși tineri respiră acest aer nesănătos pentru dezoltarea și creșterea lor profesională și spirituală. Într-o astfel de societate, mărturisirea păcatelor sau spovedania intră într-o criză fundamentală, deoarece tânărul nu se mai simte responsabil de propriul trecut, nici interesat de propriul viitor, ci se mulțumește să ducă o existență vegetativă în prezent ${ }^{9}$. Tinerii trăiesc din multe puncte de vedere o suspendare în prezent. Mulți dintre aceștia preferă să-şi închipuie propriul viitor ca rezultatul unor circumstanțe externe și inevitabile, ale căror dinamici interioare scapă posibilităţilor lor individuale de orientare, de control și de intervenție. Acest lucru apare, în special, la ultimele generații, crescute într-o lume a complexității și a incertitudinii. Din cauza faptului că aceștia nu-și pot crea și decide propria viață și nu dispun

\footnotetext{
${ }^{8}$ Savatie Baștovoi, Ortodoxia pentru postmoderniști, București, Edit. Chatisma, 2007, p. 160.

9 Teofil Tia, Elemente de Pastorală Misionară pentru o societate postideologică, Alba Iulia, Edit. Reîntregirea, 2003, p. 364.
} 
de mijloacele prin care să-și conducă existența spre un scop dorit, dezvoltă un puternic sentiment al limitei, al neputinței și al dependenței.

Sfinții Părinți vorbesc despre o lenevie a sufletului și a trupului, care este provocată de lipsa motivației și a unui scop pe care trebuie să îl atingi. Din această lenevie se naște starea de plictiseală și de permanentă oboseală la nivel fizic și psihic, care caracterizează întreg spațiul tinerei generații. Un tânăr dintr-o societate anesteziată, cu greu va reacționa la mesajul creștin în condițiile în care acesta va fi redus doar la un conținut teoretic, însă va fi puternic schimbat interior de o credință a experienței. Religia ca experiență îl va fascina pe tânărul de azi. Învățătura teoretică nu are alt scop decât acela de a1 conduce pe om spre o experiență interioară și personală cu Dumnezeu.

\section{Tânărul creștin pandant cu provocările societății postmoderne}

În zilele noastre, provocările societății sunt foarte complexe și, din cauza aceasta, misiunea Bisericii și a preotului devine mult mai dificilă. Biserica lui Hristos este chemată la o slujire mereu nouă, pentru a răspunde, în duhul Evangheliei, dificultăților pe care contextul actual, impregnat de procesul secularizării, le acumulează. Biserica nu trebuie să fie însă surprinsă de acest fenomen, deoarece ea însumează o dimensiune universală şi veșnică. Întreaga viziune a Bisericii se realizează în perspectivă universală, adresându-se tuturor oamenilor care sunt chemați de către Dumnezeu la mântuire ${ }^{10}$.

Provocarea esențială a tinerei generații în postmodernitate este conturarea unei noi paradigme antropologice, care devine pe zi ce trece tot mai individualistă. Ego-ul devine obiectivul noii idolatrii postmoderne, iar sub influența seducției pluralității sacrului apar o serie de alți idoli ai momentului, cum ar fi: bunăstarea materială,

\footnotetext{
${ }^{10}$ Anastasios Yannoulatos, Ortodoxia și problemele lumii contemporane, trad. Gabriel Mândrilă, Constantin Coman, București, Edit. Bizantină, 2003, p. 194196.
} 
idealurile politice, ascensiunea în viața profesională și vedetele din toate domeniile pe care mass-media le promoveazăa $\breve{a}^{11}$. Societatea postmodernă dezvoltă un sistem existențial, în care se încearcă cultivarea unor mentalităţi anticreștine și antireligioase. Dacă în trecut ateismul se prezenta $\mathrm{cu}$ decența și respectul unei bune relaționări în plan social, astăzi constatăm că avem de a face cu un elan nemaipomenit al nihilismului și cu manifestări și atitudini nefirești, care determină violențe teroriste extreme. Mentalitatea postmodernă duce, inevitabil, spre secularism care este mult mai periculos decât ateismul, deoarece beneficiază de o mască a falsei declarări a apartenenței religioase ${ }^{12}$.

O caracteristică a crizei tinerei generații este izolarea în rețea. Tânărul se izolează pe zi ce trece prin tehnica pe care o folosește. Observăm că persoanele interacționează între ele grație telefoniei mobile, a internetului și a televiziunii. Din punct de vedere informatic, suntem tot mai apropiaţi unul de celălalt, având atâtea mijloace de comunicare, însă conținutul acestei comunicări este tot mai puțin orientat spre adevărata comuniune ${ }^{13}$.

Între tânăr și tehnologie se realizează o relație personală, de la sclav la stăpân. Tehnologia nu este un ansamblu de mașini, așa cum averea nu reprezintă o simplă acumulare de capital. Triada BaniTehnologie-Confort a ajuns să monopolizeze relațiile interpersonale, întrucât își atribuie o realitate de sine stătătoare, o valoare intrinsecă și, mai ales, o putere autonomă. Tânărul crede că se folosește de această triadă, însă, în realitate, ele îl manipulează, transformându-1 într-un obiect. Nici banii și nici tehnologia nu sunt rele, ci doar înșelătoare și totalitare și de aceea omul trebuie să păstreze un echilibru între el, ca persoană, și acele pseudopersoane. Acolo unde

\footnotetext{
${ }^{11}$ Carmelo Dotolo, Un cristianesimo possibile. Tra postmodernità e ricerca religiosa, Brescia, Edizioni Queriniana, 2007, p. 135.

${ }^{12}$ David Pestroiu, Misiunea Bisericii față de tineri, în postmodernitate, în vol. „Relaţia dintre parohie şi şcoală în viaţa şi misiunea Bisericii din contextul actual", coordonatori: Adrian Lemeni, David Pestroiu, București, Edit. Basilica a Patriarhiei Române, 2015, p. 273.

${ }^{13}$ Anastasios Yannoulatos, op. cit., p. 366.
} 
triada Bani-Tehnologie-Confort domină, prezența omului și a lui Dumnezeu este doar tolerată. Biserica este cea care poate răsturna această triadă demonică ce îi oferă tânărului o falsă viziune asupra vieții, în vreme ce Dumnezeu Cel Întreit este libertatea adevărată. Biserica ne face să trăim fiecare clipă a vieții noastre ca un eveniment eclezial, iar tânărul este chemat să devină părtaș al Eternității vii. Plasat sub orizontul eternității - pe care nu-l poate găsi în afară și rupt de trupul Bisericii-tânărul are bucuria de a descoperi o perspectivă și un mod de existență evenimențial. Ideea este că persoana nu poate fi separată de eveniment. Personalizarea nu are efecte durabile dacă nu este evenimențială. Modelul este dat de Euharistie sau de Cina euharistică, unde se schimbă modul de existență al omului și felul său de a dialoga cu lumea ${ }^{14}$.

Biserica nu se împotrivește avansului tehnologiei, dar atrage atenția că există pericolul pentru persoana umană ca, în toată această avalanșă de descoperiri tehnologice, omul să devină robul propriilor cuceriri științifice. Poate cea mai mare provocare adresată tânărului de astăzi este atentatul la libertatea persoanei umane. Tehnologia, în general, și rețelele de comunicații, cele de internet, în special, par să devină centrul în jurul căruia gravitează tinerii din societatea contemporană. Tehnologia avansată din ziua de astăzi tinde să diminueze dimensiunea interpersonală dintre oameni, astfel încât omul devine sclavul creației, şi nu stăpânul acesteia ${ }^{15}$. Postmodernitatea mai aduce cu sine o serie de elemente idolatre. Pe primul plan aici este omul, privit în sine ca un dumnezeu. Apoi avem nenumărați idoli din lumea muzicii, a sportului sau a modei, care prin intermediul mass-media îşi expun public cele mai intime momente din viața lor, creând adevărate drame în rândul așa zișilor fani ${ }^{16}$.

${ }^{14}$ Ovidiu Hurduzeu, Tinerețe întru eveniment, în vol. „Paradoxul creștin și cartea tinereții”, Alba Iulia, Edit. Reîntregirea, 2008, p. 359-364.

${ }^{15}$ Gheorghe Holbea, op. cit., p. 265.

${ }^{16}$ Carlo Maccari, Aspetti relativistici dello gnosticismo e della New Age, în vol. "Il relativismo religioso sul finire del secondo millenio", Gruppo di ricerca e di informazione sulle Sètteretariato per l'ecumenismo e il dialogo della 


\section{3. Îndrăzneala tinerilor - speranța și viitorul Bisericii!?}

Tinerii sunt speranţa Bisericii, deoarece ea identifică în vocaţia şi misiunea tinerilor o formă autentică de apostolat în lumea în care ei trăiesc şi se dezvoltă ca oameni, în familie, la muncă sau în orice alt context social. Biserica nu se uită la tineri ca la o speranţă pentru sine, un fel de proiecţie a sa, aruncând asupra lor o responsabilitate care nu le aparţine, şi nu îi invită să urmeze o cale de sfinţenie care contravine vieţii lui Hristos, ci este vorba de o sfinţenie gândită pentru lumea în care ei trăiesc. Biserica se uită la tineri şi le cere responsabilitate și implicare, se bazează pe ei, are încredere în acţiunile, abordările şi iniţiativele lor. Aceasta crede că ei caută ceva nou şi că experienţa şi întrebările lor cer un astfel de angajament. În aspiraţiile tinerilor, Biserica vede ceva din speranţa care o susţine şi care încurajează întâlnirea şi dialogul. Din moment ce Biserica este o instituție divino-umană, fiecare dintre membrii săi trebuie privit în acelaşi fel, dintr-o perspectivă a credinţei întrupate care acceptă lumea şi o transformă conform Scripturii, condusă de Duhul Sfânt, căutând calea spre Împărăţie. Biserica îi priveşte pe tineri ca membri activi și preţioşi ai societăţii, cărora le răspunde cu credinţă şi speranţă ${ }^{17}$.

Pentru Biserică, influenţa pe care aceşti tineri o exercită în societate şi felul cum acționează în unele situaţii merită respect. În haosul și derapajul moral actual al societăţii, nimeni nu poate scăpa de impactul schimbării, mai ales tinerii, care au responsabilităţi încă de la o vârstă fragedă, pentru care nu sunt întotdeauna pregătiţi (şi pentru care adesea nu au fost pregătiţi de ceilalţi), în familie, în lumea muncii şi a deciziilor fără număr pe care sunt chemaţi să le facă fără o pregătire în prealabil şi cu maturitate, totuşi. Creşterea valorii lor în societate şi formarea umană şi spirituală pe care ei

Conferenza Episcopale italiana, Università Cattolica del Sacro Cuore, Città del Vaticano, Libreria Editrice Vaticana, 1996, p. 172.

17 Cesar Kuzma, Church, Hope and Young People, in "Concilium", International Journal of Theology, t. 2, Edited by Solange Lefebvre, Maria Clara Bingemer, London, SCM Press, 2015, p. 60-61. 
trebuie să o primească va creşte doar prin angajamentul lor în misiunea apostolatului social. De cealalată parte stă Biserica, cea care investeşte în ei credinţa şi îi cheamă la misiune. Dacă Biserica investeşte în ei speranţă, are datoria şi responsabilitatea serioasă de a sprijini această speranţă cu toate forţele pe care le posedă. Speranţa nu poate fi gândită în izolare, dar cu şi în noi toţi, pentru alţii şi cu alţii, trebuie să fie întotdeauna o speranţă colectivă ${ }^{18}$.

Tinerețea este o vreme a întrebărilor care au nevoie de răspunsuri. De aceea, vine tânărul cel bogat la Hristos și îl întreabă ce să facă pentru a se mântui. La un moment dat, Hristos îi spune: $S \breve{a}$ nu fii desfrânat. Iar tânărul îi răspunde: Păzesc toate acestea din tinerețile mele. Tânărul din Evanghelie reușise să-și țină în frâu patimile, pentru că nu erau tare crescute în el, pentru că putea lucra în direcția patimilor pe care acum le denigra și spunea că el nu a trecut prin problema aceasta. Și Mântuitorul îi spune: Ține exact ceea ce nu poți ține. Și îl lovește exact acolo unde el credea că este foarte puternic: Vinde tot ceea ce ai, dăruiește săracilor și urmează-Mi Mie (Mt. 19, 16-22). Același mesaj ni-l adresează și nouă, celor de astăzi. În acest sens, părintele Constantin Necula afirmă faptul că unor tineri nu le este greu să meargă la biserică, ci le este greu doar dacă chefuiesc de sâmbătă noaptea până spre duminica dimineața și fac din căminele studențești lupanare fără firmă. Și atunci, care ar fi răspunsul Ortodoxiei? Fă ceea ce ți se pare că nu poți să faci. Te plângi că nu poți să te rogi? Roagă-te! Te plângi că n-ai din ce să faci milostenie? Rupe jumătate din mâncarea ta și dă celui care nu are! Acesta este modelul pe care Hristos ni-1 oferă și vrea să-l urmăm ${ }^{19}$.

De cele mai multe ori, în Biserică, atunci când întrebăm de ce un lucru se face așa și nu altfel, cel mai frecvent răspuns primit este: așa se face. Tinerii nu acceptă explicații de genul acesta. Acesta nu este un argument. Ei vor să știe de ce Sfânta Liturghie este așa și nu

18 Benedict XVI, Spe salvi, 14: http://w2.vatican.va/content/benedictxvi/en/encyclicals/documents/hf_ben-xvi_enc_20071130_spe-salvi.html

(accesat la data de 20.04.2016).

19 Constantin Necula, Tinerețea Ortodoxiei, seria conferințe, Sibiu, Edit. Agnos, 2004, p. 15-17. 
altfel, de ce ne închinăm la icoane, de ce se cântă într-un anumit fel. Vor să cunoască rostul tuturor lucrurilor din Biserică. În ultimii ani, au apărut o serie de autori tineri care încearcă să prezinte credința pe înțelesul tuturor, însă fără prea mulți sorți de izbândă, deoarece aceștia cred că au din nou de-a face cu o scriere sofisticată și greoaie, ruptă de realitate și neancorată în prezent ${ }^{20}$.

\section{Concluzii}

Timpul de astăzi este un timp al transformărilor continue, pe toate palierele existenţei: social, economic, informaţional şi spiritual. Această metamorfoză galopantă reverberează într-un mod benefic sau mai puţin benefic şi asupra vieţii religioase, afectând-o fie în integritatea ei, fie pe un anumit segment. Sigur că efectele acestor transformări şi dezvoltări continue se răsfrâng asupra tuturor categoriilor de persoane. Nu scapă de acest lucru nici tinerii, care cad pradă acestei acţiuni, şi astfel devin nişte căutători neopriţi. Însă salvarea tânărului este că

„prin definiţie, el niciodată n-a fost anacronic. A fost şi este în pas cu vremea şi se raportează mereu la factorul modern, având mereu o privire de perspectivă asupra realităţii. Realitatea reprezintă pentru el sursa ce-i alimentează resursele şi care îl veghează, îl orientează, dar şi îl asaltează. Realitatea rămâne pentru tânăr o perpetuă provocare" ${ }^{, 21}$.

Criza morală și lupta de formare a personalităţii cer imperios energiile de luptă și biruință ale rugăciunii. $\mathrm{Nu}$ există tinerețe biruitoare fără rugăciune. Așa cum culorile petalelor sunt pictate în auriul razelor de soare pe care mugurul de pe creangă le soarbe în sine, armonia personalităţii crește din luminile cerului, pe care

\footnotetext{
${ }^{20}$ Bogdan Mateciuc, Tinerii față în față cu Biserica, în vol. „Paradoxul creștin și cartea tinereții”, Alba Iulia, Edit. Reîntregirea, 2008, p. 216.

${ }^{21}$ Constantin Necula, Mihai Iosu, Tinerii şi ispitele modernismului, Sibiu, Edit. Agnos, 2008, p. 37.
} 
tinerețea le soarbe în rugăciune. Rugăciunea este adevărata putere formativă a tinereții, pentru că ea Îl coboară pe Dumnezeu în suflet, pe Dumnezeu Cel Ce creează și plăsmuiește toate ${ }^{22}$.

În cazul tinerilor, este nevoie de o serioasă selecție a amalgamului de informații care îl bombardează zilnic și de educarea gustului spre frumos și sublim. Tânăra generație poate să influențeze întreaga societate, iar în acest, sens Sfântul Ioan Gură de Aur spunea: Dați-mi mame bune şi voi schimba fața lumii! Cuvintele Sfântului sunt actuale, și în același timp, apocaliptice, în sensul în care, dacă dobândești duhovnicește o generație tânără, este ca și cum ai învia o națiune, dacă pierzi sau pervertești o generație tânără, este ca și cum ai ucide o națiune întreagă.

\section{Bibliografie}

1. Ahern, Kevin, Youth Movements in a Global Church, in "Concilium", International Journal of Theology, t. 2, Edited by Solange Lefebvre, Maria Clara Bingemer, London, SCM Press, 2015.

2. Baștovoi, Savatie, Ortodoxia pentru postmoderniști, București, Edit. Chatisma, 2007.

3. Benedict XVI, Spe salvi, 14: http://w2.vatican.va/content/benedictxvi/en/encyclicals/documents/hf ben-xvi_enc_20071130_spe-salvi.html (accesat la data de 20.04.2016).

4. Himcinschi, Mihai, Confruntări misionare: știința şi teologia, în „Altarul Reîntregirii”, anul XI, nr. 2, mai-august, 2006.

5. Holbea, Gheorghe, Pastorația tinerilor în contextul actual al globalizării, în „Relaţia dintre parohie şi şcoală în viaţa şi misiunea Bisericii din contextul actual", coordonatori: Adrian Lemeni, David Pestroiu, București, Edit. Basilica a Patriarhiei Române, 2015.

6. Hurduzeu, Ovidiu, Tinerețe întru eveniment, în vol. „Paradoxul creștin și cartea tinereții”, Alba Iulia, Edit. Reîntregirea, 2008.

${ }^{22}$ Nicolae Mladin, Tineretul și rugăciunea, în vol. „Tineretul și creștinismul. Repere duhovnicești pentru tinerii zilelor noastre", Craiova, Edit. Mitropoliei Olteniei, 2008, p. 160. 
7. Kuzma, Cesar, Church, Hope and Young People, in "Concilium", International Journal of Theology, t. 2, Edited by Solange Lefebvre, Maria Clara Bingemer, SCM Press, London, 2015.

8. Maccari, Carlo, Aspetti relativistici dello gnosticismo e della New Age, în vol. "Il relativismo religioso sul finire del secondo millenio", Gruppo di ricerca e di informazione sulle Sètteretariato per l'ecumenismo e il dialogo della Conferenza Episcopale italiana, Università Cattolica del Sacro Cuore, Città del Vaticano, Libreria Editrice Vaticana, 1996.

9. Mateciuc, Bogdan, Tinerii față în față cu Biserica, în vol. Paradoxul creștin și cartea tinereții, Alba Iulia, Edit. Reîntregirea, 2008.

10. Mladin, Nicolae, Tineretul şi rugăciunea, în vol. „Tineretul şi creștinismul. Repere duhovnicești pentru tinerii zilelor noastre”, Craiova, Edit. Mitropoliei Olteniei, 2008.

11. Necula, Constantin, Tinerețea Ortodoxiei, seria conferințe, Sibiu, Edit. Agnos, 2004.

12. Necula, Constantin, Iosu, Mihai, Tinerii şi ispitele modernismului, Sibiu, Edit. Agnos, 2008.

13. Pestroiu, David, Misiunea Bisericii față de tineri, în postmodernitate, în vol. „Relaţia dintre parohie şi şcoală în viaţa şi misiunea Bisericii din contextul actual", coordonatori Adrian Lemeni, David Pestroiu, București, Edit. Basilica a Patriarhiei Române, 2015.

14. Tia, Teofil, Elemente de Pastorală Misionară pentru o societate postideologică, Alba Iulia, Edit. Reîntregirea, 2003.

15. Trif, Ilie, $N u$ te încuia în deznădejde, în vol. Paradoxul creștin și cartea tinereții, Alba Iulia, Edit. Reîntregirea, 2008.

16. Yannoulatos, Anastasios, Ortodoxia și problemele lumii contemporane, trad. Gabriel Mândrilă, Constantin Coman, București, Edit. Bizantină, 2003. 